\title{
Political Violence in the Upcountry Tea Plantation Areas: A Study in Nuwara Eliya Pradeshiya Sabha Area
}

\author{
BM \\ Loganathan Vijayanathan \\ Reg. No. GS/SS/147/612001
}

M.Se Human Security

June 2004 


\section{Declaration}

The work described in this thesis was carried out by me under the supervision of Dr. S.I. Keethaponcalan and a report on this has not been submitted in whole or in part to any University for another Degree Programme.

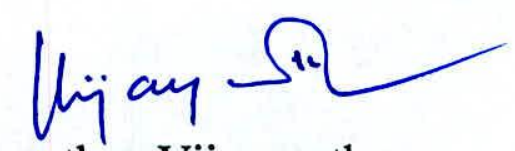

Loganathan Vijayanathan

Date: 14.7 .2004 


\section{Declaration by the Supervisor}

I certify that the above statement made by the candidate is true and that this thesis is suitable for submission to the University for the purpose of evaluation.

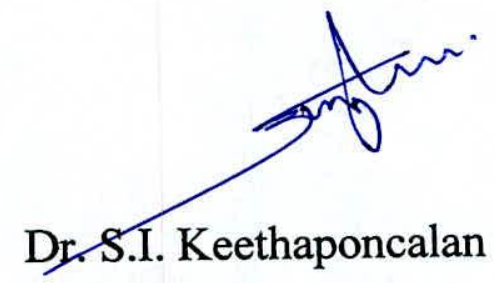

Date: 14107104

Senior Lecturer - Department of Political Science

University of Colombo 


\section{POLITICAL VIOLENCE IN THE UPCOUNTRY TEA}

PLANTATION AREAS:

A STUDY IN NUWARA ELIYA PRADESHIYA SABHA AREA

BY

LOGANATHAN VIJAYANATHAN

THESIS SUBMITTED TO THE UNIVERSITY OF SRI

JAYAWARDANEPURA AS A PARTIAL FULFILMENT FOR THE AWARD OF THE DEGREE OF MASTER OF SCIENCE IN HUMAN SECURITY - JUNE 2004 


\section{DEDICATION}

This Research Report is dedicated to my mother Shrimati Vijayaletchumi Loganathan and father late Shri R.V.

Loganathan Naidu. 


\section{ACKNOWLEDGEMENT}

This piece of Research would have been impossible if not for the tireless support and encouragement given to me by my supervisor Dr. S.I. Keethponcalan, Senior Lecturer Department of Political Science, University of Colombo. I thank him whole-heartedly.

My special thanks to Dr. Deharagoda for his continued support with an understanding of our regular work an encouragement given to all of us in the Human Security programme.

It is with deep appreciation I thank my fired Mr. Shanthakumar of the Central Province, Ministry of Education for his support during my field work in Nuwara Eliya. I also wish to place my appreciation to Mr. Balendran, Mr. Yogesh and Mr. Athimani for helping me in my field work. I also thank Channa and Vijitha for their continued assistance for my studies.

It would have been impossible to write my thesis if not for the support from my beloved wife Dharshini who assisted throughout my course and research work. I wish to acknowledge the help and assistance given to me by brother in law Suresh and nephew Eshodharar.

Last but not least I wish to record my gratitude to all my respondents for their free and frank discussions during the interviews which helped me immensely in my analysis and report writing. 


\section{ABSTRACT}

Political violence has come to the forefront dominating the electoral process and also the governance at various levels. While the causes of such violent acts are different and manifold, the affects also differ in its extent of damages and its intensity. This research was undertaken to study the violence with political characteristics in the tea Plantation Areas affecting the Upcountry Tamil Community in Sri Lanka. When we consider political violence of the Upcountry Tamil community it automatically implies the act of trade unions that have caused violent incidents that have severely disrupted the normal life of the people in that area. Violence with political dimension since Upcountry Tamils are a distinct minority. Given the scope and complexity of the study, it was undertaken in Nuwara Eliya Pradeshiya Sabha Area in Nuwara Eliya district of the Central Province of Sri Lanka.

The research study has explored the positive relationship between the violent actions of the Upcountry Tamils with the Trade Union action. There is a clear link between the micro level clashes between the individuals and groups to the macro level violent incidents in the event of those whom clashing at the micro level are from different trade unions or with affiliations to different political parties. The action of the police exacerbates the condition when there is interference from the powerful $T U$, which is a common scenario. The TU also to demonstrate its dominance over the other propagates violent means through the use of youth members. The political clashes have not been as server as in other areas of the country. 
The Conditions prevailing in the upcountry especially in the tea plantations may have lead to a state of depression and frustration that would have lead to violent incidents. Their perception is that the continued discriminatory conditions is a barrier for them to realize their unfulfilled human needs for mainly security and recognition and that they are increasingly not willing to accept that position. It is also manifested by their action of meeting violence with violence during the communal riots that took place in the year 1987 and 2000.

Having fewer opportunities to further their skills for marketable employment they were confined to the estates that has lead to frustration that generally leads for aggressive behavior. The social conditions in the Upcountry the plantations exacerbates this situation. Having fully realized that a rebellious action is not possible given the geographical terrain of the upcountry, the youth are of the opinion that such action alone could bring recognition to their problem. This perception is not a good sign in the promotion of peace and reconciliation in the country.

\section{Vijayanathan}

24 June 2004 


\section{List of Abbreviations}

\begin{tabular}{ll} 
ACEWU & All Ceylon Estate Workers Union \\
ACEWF & All Ceylon estate Workers Federation \\
BW & Bindunuwewa \\
CIC & Ceylon Indian Congress \\
CICLU & Ceylon Indian Congress Labour Union \\
CWC & Ceylon Workers Congress \\
CDC & Ceylon Democratic Congress \\
DWC & Democratic Workers Congress \\
LJEWU & Lanka Jathika Estate Workers Union \\
LSSP & Lanka Sama Samaja Party \\
LTTE & Liberation Tigers of Tamil Eelam \\
TULF & Tamil United Liberation Front \\
TU & Trade Union \\
UPF & Upcountry Peoples Front \\
UNP & United National Party \\
VV & Veera Vidanaya \\
\hline
\end{tabular}




\section{TABLE OF CONTENTS}

CHAPTER 1 - INTRODUCTION ........................................................................................................

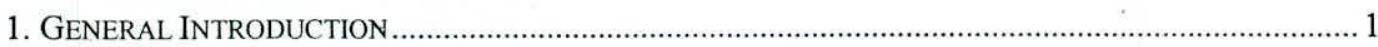

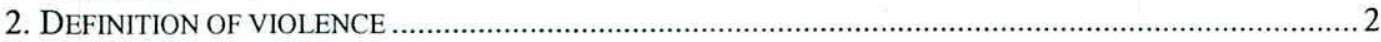

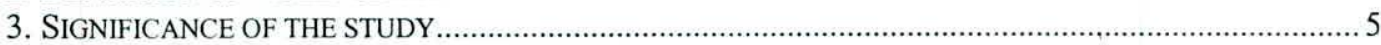

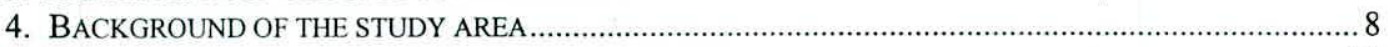

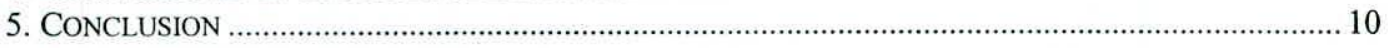

CHAPTER 2 - CONCEPTUALIZA IION AND THEORETICAL CONSTRUCT .........................11

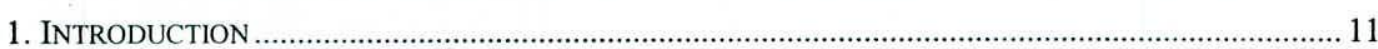

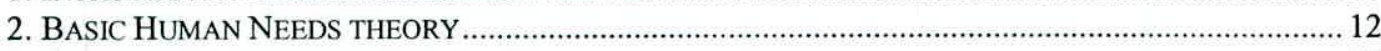

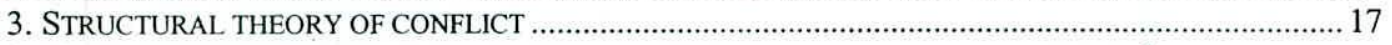

4. VIOLENCE WITH POLITICAL CHARACTERISTICS IN THE TEA PLANTATION AREAS IN SRI

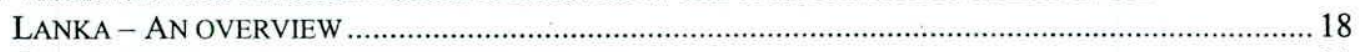

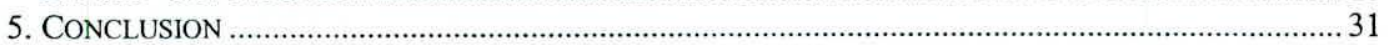

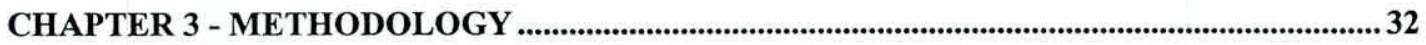

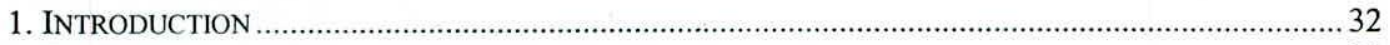

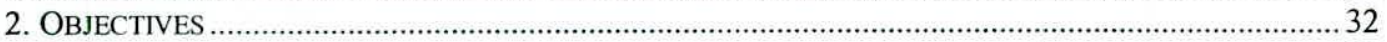

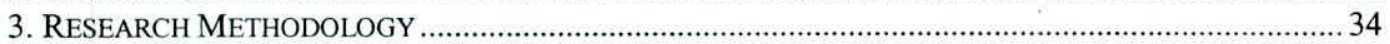

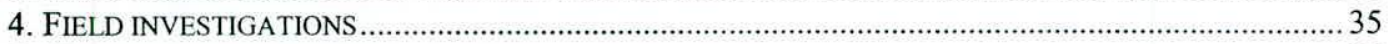

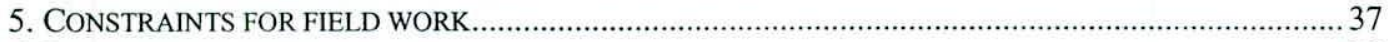

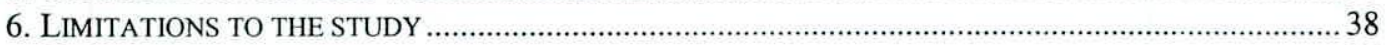

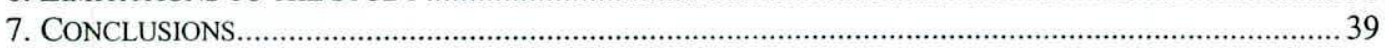

CHAPTER 4 - HISTORY OF THE UPCOUNTRY TAMIL COMMUNITY................................40

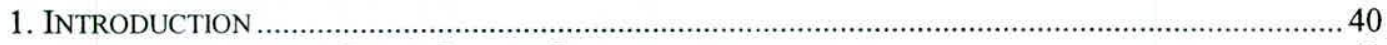

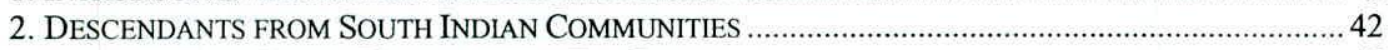

3. EVOLUTION OF TRADE UNIONS IN THE TEA PLANTATIONS............................................................... 47

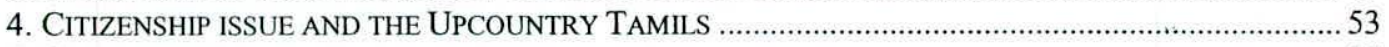

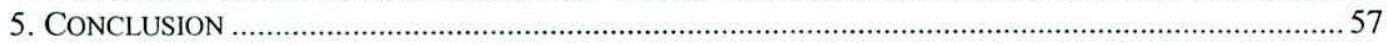

CHAPTER 5 - GROWING UNREST IN THE UPCOUNTRY ......................................................60

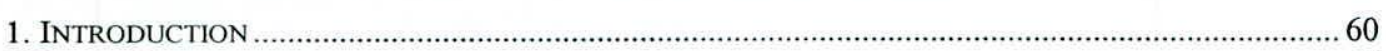

2.TRADE UNIONS AND THEIR ROLE IN THE POLITICAL VIOLENCE .....................................................6 60

3. ETHNIC BASED VIOLENCE IN THE UPCOUNTRY TEA PLANTATION AREAS .......................................94

4 REFLECTION OF THE ONGOING ETHNIC CONFLICT TO THE VIOLENCE IN THE PLANTATIONS............. 108

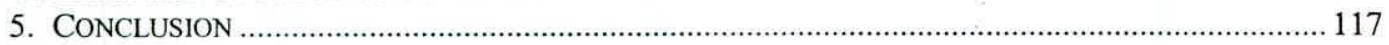

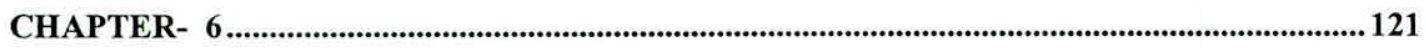

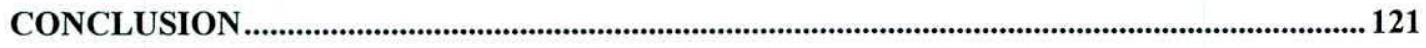

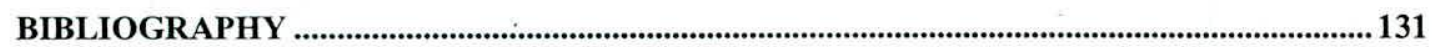

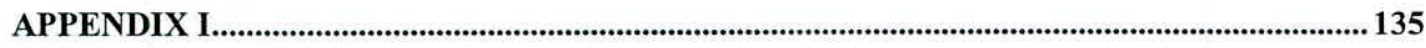

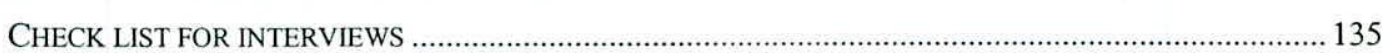




\section{Chapter -1}

\section{Introduction}

\section{General Introduction}

Violence has inevitably come to the forefront of political, social and cultural life in Sri Lanka more particularly since the early 1970s. Political violence pre-dominated the electoral process and spread all over the country with different intensities. While the causes of violence are different and manifold, the affects also differ in its extent of damages and its intensity. This research report is an outcome of study of 'The Political Violence in the Tea Plantation Areas' affecting the Upcountry Tamil Community in Sri Lanka. The study was undertaken to analyse the causes of violence emerging from a political perspective that were perpetrated by and against the community for various reasons. The study focused to find out the major causes for political violence in the plantation areas and what provocative factors that leads for the people to involve in violent acts in these areas. Human Needs Theory was studied in detail to relate violence and identify actual causes of the violence concerning the Upcountry Tamil Community. The study was undertaken in Nuwara Eliya Pradeshiya Sabha Area in Nuwara Eliya District, which comprises Nuwara Eliya, Thalawakele, Kotagala, Patana, Agarapatana and Diyagama towns and the adjoining Tea estates. 


\section{Definition of violence}

Understanding of the term violence in general is complex or sometimes vague. The society views violence in many different ways with overall perception of that it is a causative of injury to people and property (Silva, 1996). Most people will probably agree that homicide represents violence, but differences arise when we consider violence as actions of governments, police agencies, etc. Violence could be viewed in the perspective of criminal justice, social services, legal, medical and public health among others. Most of the research has focused on violence related to crime (Moore, 1990). The other important aspect of violence is domestic violence, which is widely addressed today.

Most attention focuses upon interpersonal violence (aggression by one or more persons against another). Another category of violence outside of this realm is violence directed against oneself. In lay terms, this refers to suicides or suicide attempts (Biyanwila, 1997).

To understand the importance of the problem it is important to define the term violence. Attempts have been made to define violence from a criminal justice perspective, a domestic violence perspective, an injury perspective, a medical perspective, and a sociological perspective, among others (Moore, 1990). There are few agreed upon standards regarding the appropriate definition for violence. The earliest works all considered violence primarily from the perspective of policereported crimes. Recent works have broadened the characterization of violence. Violence was defined (Reiss. A.J and Jeffrey, 1993) as "behavior by persons against persons that intentionally threatens, attempts or actually inflicts physical harm". This 
definition includes both physical injury and threats. It does not include self-directed violence.

The Concise Oxford Dictionary defines violence as unlawful exercise of physical force. Olweus (1999) quoted by Moore' also confines violence to the use of physical force. He defines violence/violent behaviour as aggressive behaviour where the actor or perpetrator uses his or her own body as an object (including a weapon) to inflict (relatively serious) injury or discomfort upon an individual.

However, violence has been defined in a broader sense to include behaviour by people or against people liable to cause physical or psychological harm (Gulbenkian Foundation, 1995).

Violence is also explained as behaviour of persons against others that intentionally threatens, attempts, or actually inflicts physical harm. This explanation includes both physical injury and threats. It does not include self-directed violence. In this research thesis violence is studied in the tea plantation covering issues related to political aspects. The violent incidents that have taken place in the tea plantation areas had lead to disruption of social and economic life of the community either for short or long time period. These violent incidents would have been as a result of aggressiveness. However it should be noted that aggressive behaviour is not apart from social conditions or aggression does not necessarily end in violent action. Social influences are likely to make individual behave violently (Turpin, 1997). 
Hartogs \& Artzt (1970) quoted by Johan M.G. first identified organised violence, which is "patterned and deliberate". All organized violence is instrumental in the sense that it is one means of social combat among many, and it functions in a context of group interests and goals. The second type of violence is spontaneous violence, which is an "unplanned explosion set off by the unique chemistry of internal and external conditions". While organized violence is both instrumental and impersonal, spontaneous violence is reactive, compensatory, or gratuitous. As a reaction, it is a way of striking out directly against frustration. As compensation, it is a way of making up for frustrations suffered in the past. As gratuitous violence, it is a way of displacing aggression from an object, which cannot be attacked (because it is too powerful or because it generates ambivalent feelings) to an object which is too weak to resist and which arouses clear feelings. Spontaneous violence may be collective or individual.

Organized violence may be divided into criminal and political types (Grundy \& Weinstein, 1974). Criminal violence, while impersonal or instrumental, is not directed at the defence, disruption or restoration of a normative order, although it may unwittingly contribute to such outcomes. Political violence is directed at the maintenance or change of a normative order.

Violence in this study is the causation of the harm or injury to property and life arising through deliberate action by the community themselves or action that is directed against the community. The definitions mentioned above include apart from physical injury also the 'threat'. The 'threat' that leads to the disruption of normal life. 
Therefore, in this study the act that has threatened the normal people and that has caused disruption of normalcy in the areas has also been looked at.

In the above context an attempt was made to define political violence for the purpose of this research as a 'process where deliberate use of physical force or threat is carried out with an intention to cause death or injury to persons or destruction of property and or disruption of normal life by organised groups or members of such entities to their perceived political enemy'.

In this study the focus will be on violence with political characteristics, which in the plantations has caused intentional threats or actual harm in the form of physical injury to the persons and property and attempts that disrupt normal life for political gains. However since the trade unions play an important role as political units in the plantations areas the action of trade unions, which are of violent nature and caused conditions that are explained above are considered to be political violence. These acts by the trade unions can also be considered as for gaining political supremacy in the plantation areas and or in the national politics of the country. All other forms of violence be it domestic or otherwise has not been dealt in this study.

\section{Significance of the study}

Violence has been studied with different perspectives; broadly sociological perspective, psychological perspective, political perspective, and with specific social and economical context. In Sri Lanka attempts were made to study violence with the ethnic based and class base both in the Northern conflict to the Southern Insurrection. Academics have studied in detailed the insurrection under taken by Sinhala youth 